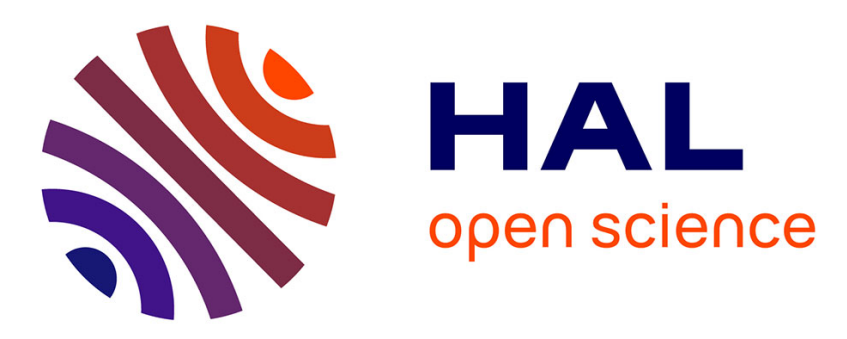

\title{
Large-scale survey of lithium concentrations in marine organisms
}

\author{
F. Thibon, L. Weppe, N. Vigier, C. Churlaud, T. Lacoue-Labarthe, M. \\ Metian, Yves Cherel, P. Bustamante
}

\section{- To cite this version:}

F. Thibon, L. Weppe, N. Vigier, C. Churlaud, T. Lacoue-Labarthe, et al.. Large-scale survey of lithium concentrations in marine organisms. Science of the Total Environment, 2021, 751, pp.141453. 10.1016/j.scitotenv.2020.141453 . hal-02928284v1

\section{HAL Id: hal-02928284 \\ https://hal.science/hal-02928284v1}

Submitted on 4 Jan 2021 (v1), last revised 4 Jan 2021 (v2)

HAL is a multi-disciplinary open access archive for the deposit and dissemination of scientific research documents, whether they are published or not. The documents may come from teaching and research institutions in France or abroad, or from public or private research centers.
L'archive ouverte pluridisciplinaire HAL, est destinée au dépôt et à la diffusion de documents scientifiques de niveau recherche, publiés ou non, émanant des établissements d'enseignement et de recherche français ou étrangers, des laboratoires publics ou privés. 


\section{Journal Pre-proof}

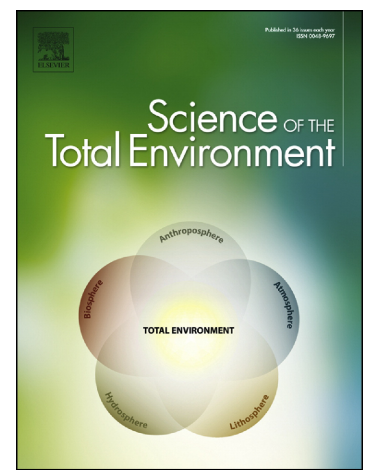

Large-scale survey of lithium concentrations in marine organisms

F. Thibon, L. Weppe, N. Vigier, C. Churlaud, T. Lacoue-Labarthe, M. Metian, Y. Cherel, P. Bustamante

S0048-9697(20)34982-2

DOI: $\quad$ https://doi.org/10.1016/j.scitotenv.2020.141453

Reference: $\quad$ STOTEN 141453

To appear in: $\quad$ Science of the Total Environment

Received date: $\quad 13$ May 2020

Revised date: $\quad 24$ July 2020

Accepted date: $\quad 1$ August 2020

Please cite this article as: F. Thibon, L. Weppe, N. Vigier, et al., Large-scale survey of lithium concentrations in marine organisms, Science of the Total Environment (2020), https://doi.org/10.1016/j.scitotenv.2020.141453

This is a PDF file of an article that has undergone enhancements after acceptance, such as the addition of a cover page and metadata, and formatting for readability, but it is not yet the definitive version of record. This version will undergo additional copyediting, typesetting and review before it is published in its final form, but we are providing this version to give early visibility of the article. Please note that, during the production process, errors may be discovered which could affect the content, and all legal disclaimers that apply to the journal pertain.

(C) 2020 Published by Elsevier. 


\section{Large-scale survey of lithium concentrations in marine organisms}

F. Thibon ${ }^{\mathrm{a}^{*}}$ \& L. Weppe ${ }^{\mathrm{a}^{*}}$, N. Vigiera, C. Churlaud-, T. Lacoue-Labarthe ${ }^{\mathrm{b}}$, M. Metian ${ }^{\mathrm{c}}$, Y. Cherel $^{\mathrm{d}}$ and P. Bustamante ${ }^{\mathrm{b}, \mathrm{e}}$

${ }^{a}$ Laboratoire d'Océanographie de Villefranche-sur-Mer (LOV), UMR 7093, CNRS, Sorbonne université, 06230 Villefranche-sur-Mer, France

${ }^{b}$ Littoral Environnement et Sociétés (LIENSs), UMR 7266 CNRS- La Rochelle Université, F17000 La Rochelle, France

${ }^{c}$ International Atomic Energy Agency, Environment Laboratori ?s, 4a, Quai Antoine 1er, MC98000, Principality of Monaco, Monaco

${ }^{d}$ Centre d'Etudes Biologiques de Chizé, UMR7372 du CNRS- a n shelle Université, 79360 Villiers- en-Bois, France

${ }^{e}$ Institut Universitaire de France (IUF), 75005 Paris, Fran ${ }^{-e}$

* Co-First authorship

Corresponding author: fanny.thibon@obs-vlfr.fr

\section{Abstract}

Trace metals such as $\mathrm{Cu}, \mathrm{Hg}$, and $\mathrm{Zn}$ hav heen widely investigated in marine ecotoxicological studies considering their bioaccumul ain, transfer along trophic webs, and the risks they pose to ecosystems and human health. Cor. paratively, Li has received little attention, although this element is increasingly used i- this high-tech, ceramics/glass, and medication industries. Here, we report $\mathrm{Li}$ concentrations in more than 400 samples, including whole organisms and different organs of bivalves, cept llopods, crustaceans, and fish. We investigated species from three contrasting biogeographic areas, i.e. temperate (Bay of Biscay, northeast Atlantic Ocean), tropical (New Caledonia, Pacific Ocean) and subpolar climates (Kerguelen Islands, southern Indian Ocean), among diverse trophic groups (filter-feeders to meso-predators) and habitats (benthic, demersal, and pelagic). Although $\mathrm{Li}$ is homogeneously distributed in the ocean (at 0.18 $\mu \mathrm{g} / \mathrm{mL}$ ), Li concentrations in soft tissues vary greatly, from 0.01 to $1.20 \mu \mathrm{g} / \mathrm{g}$ dry weight. A statistical linear model indicates that trophic group, habitat, location, organ, and taxonomy, each contribute to the observed variability in Li concentrations. Multiple correspondence analyses 
reveal two clusters of high and low $\mathrm{Li}$ concentrations. Li distributions in marine organisms appear to be mostly geographically independent, though our results highlight a temperature dependency in fish muscles. Li is consistently bio-reduced through the trophic webs, with filterfeeders showing the highest concentrations and predatory fish the lowest. Strong variations are observed among organs, consistent with the biochemical similarity between $\mathrm{Na}$ and Li during transport in the brain and in osmoregulatory organs. Fish gills and kidneys show relatively high Li concentrations $(0.26$ and $0.15 \mu \mathrm{g} / \mathrm{g}$, respectively) and fish brains show a large range of $\mathrm{Li}$ contents (up to $0.34 \mu \mathrm{g} / \mathrm{g}$ ), whereas fish liver and muscles are $\mathrm{I} \mathrm{i}_{\mathrm{a}} \mathrm{\iota}_{\mathrm{l}}$ leted $(0.07 \pm 0.03$ and $0.06 \pm$ $0.08 \mu \mathrm{g} / \mathrm{g}$, respectively). Altogether, these results provide un tırst exhaustive baseline for future Li ecotoxicology studies in marine environments.

Keywords: ecotoxicology; bioaccumulation; trophic webs, bio-reduction; biogeography; multiple correspondence analyses

\section{Introduction}

Numerous trace metals are reie ts $\mathrm{d}$ to rivers, coastal areas, and ultimately the oceans by human activities, and their heha :ors in many marine taxa such as bivalves, cephalopods, crustaceans, and fish have $\llcorner$ sen thoroughly investigated in past decades (e.g. Bustamante et al., 2003; Eisler, 2010; ${ }^{\top}$ ein. et al., 2013). However, lithium (Li) concentrations in marine organisms have received little attention, despite the exponentially increasing use of this element in high-tech industries due to its unique physicochemical properties. $\mathrm{Li}$ in the oceans is dominantly derived from two natural sources, i.e. high-temperature hydrothermal fluxes at midocean ridges and river inputs. It exits the ocean mainly via the formation of marine authigenic aluminosilicate clays on the seafloor (Chan et al., 2006). Due to its long oceanic residence time ( 1.2 million years) and its weak capacity to adsorb onto marine particles (Decarreau et al., 2012), Li is homogeneously distributed throughout the water column (Misra and Froelich, 2012). Thus, the oceanic concentration of dissolved $\mathrm{Li}$ is constant at $0.183 \pm 0.003 \mu \mathrm{g} / \mathrm{mL}$, irrespective 
of latitude and depth (Aral and Vecchio-Sadus, 2011; Misra and Froelich, 2012; Riley and Tengudai, 1964).

Worldwide anthropogenic Li production has strongly increased in the past decade (from 28 to 43 thousand tons between 2010 and 2017), with its growing use in several industries (Labbé and Daw, 2012; USGS, 2017). Thus, Li has the highest predicted annual growth rate among metals during 2017-2025 (+18\%), far surpassing cobalt (+8.8\%; Léguérinel et al., 2018). Indeed, Li-ion batteries are expected to account for more than $80 \%$ of the total Li market in 2025, although $\mathrm{Li}$ in batteries has the worst recycling recovery rate $\mathrm{on}_{\mathrm{I}_{\mathrm{L}}}$ ared to $\mathrm{Al}, \mathrm{Co}, \mathrm{Cu}, \mathrm{Mn}$, and $\mathrm{Ni}$ (Harper et al., 2019). Li from waste-disposal practices in the JSA contaminates groundwater at levels toxic to some freshwater organisms $(50-170 \mu, / L$, and far above Li concentrations in most rivers in the USA and worldwide $(\sim 1.5 \mu \mathrm{g} / \mathrm{L})$ (e.g Fiuh el al., 1998; Kszos and Stewart, 2003). Li contamination also results from the use of agi: ultural amendments (Millot et al., 2010; Négrel et al., 2010). Recently, a positive correlatı ^ was reported between population density and Li content in the Han River and tap w... ors of the megalopolis of Seoul (Korea), highlighting the first known large-scale Li pollutın in an urban area (Choi et al., 2019). Consequently, considerable further anthrop $\sigma^{-e_{1}}{ }^{i} \mathrm{c}$ contributions of $\mathrm{Li}$ to the environment are expected in the coming decades, raising un necessity to understand the role and impact of Li in coastal and marine ecosystems.

It remains unclear how $\mathrm{Li}$ affects ecosystems. Li may be somewhat beneficial to organism health, as is the case for humans (Giotakos et al., 2013; Liaugaudaite et al., 2017; Ohgami et al., 2009; Schrauzer and Shrestha, 1990): some authors consider Li to be an essential trace element, recommending a daily Li intake of $14.3 \mu \mathrm{g} / \mathrm{kg}$ (Schrauzer, 2002). Indeed, since 1949, various forms of $\mathrm{Li}$ (mostly $\mathrm{Li}_{2} \mathrm{CO}_{3}$ ) have been used as the major treatment for bipolar disorder because Li presents a neuroprotective effect (Machado-Vieira, 2018; Szklarska and Rzymski, 2018; Won and $\mathrm{Kim}, 2017)$. However, $\mathrm{Li}_{2} \mathrm{CO}_{3}$ is poisonous beyond the maximum therapeutic dose (10.4 
$\mathrm{mg} / \mathrm{L}$ in blood; Timmer and Sands, 1999) and may lead to death at concentrations above $20 \mathrm{mg} / \mathrm{L}$ (Aral and Vecchio-Sadus, 2008; Schou et al., 1968). Above a given critical concentration, Li is also toxic to aquatic organisms, affecting some of their metabolic functions. For instance, Lienriched seawater disrupts embryogenesis in urchins, zebrafish, and amphibians (Hall, 1942; Kao et al., 1986; Kiyomoto et al., 2010; Stachel et al., 1993).

The bioconcentration of trace elements is a well-known process (Bryan, 1979) that depends on their bioavailability in a given media and their bio-accessibility in trophic sources. Thus, the chemical form of an element (dissolved, particulate, adso oec or complexed) influences its capacity for absorption and assimilation by living organis ns. 'urthermore, the concentrations of some contaminants increase along trophic levels (At $\mathrm{e}_{\mathrm{i}}$ er al., 1998). Such biomagnification is well documented in various food webs around the world ior $\mathrm{Hg}$ and organic contaminants (Kelly et al., 2007). In the ocean and coastal areas. a iotıc (temperature, salinity, $\mathrm{pH}$ ) and biotic factors (physiological characteristics, habitats, . ophic ecology) can also affect organism metalaccumulation capacities. To date, $\mathrm{I}$ - $\mathrm{or}_{\mathrm{r}}$-entrations in marine organisms and their controlling factors have not been intensively investigated (Ansari et al., 2004; Luoma, 1983). Although significant differences in $\mathrm{Li}$ ( $\mathrm{n}_{\mathrm{n}}$ `ntrations have been observed between selected marine species and organs (English et ai. 2015; Guérin et al., 2011; Noël et al., 2012), changes of Li concentrations along the $\mathrm{\iota}$ ophic webs remains unknown.

The aims of the present study are (1) to establish a biogeochemical baseline for future ecotoxicological studies in marine and coastal environments, and (2) to provide a preliminary assessment of the behavior of $\mathrm{Li}$ in food webs. Thus, we provide an extensive dataset of $\mathrm{Li}$ concentrations across different marine groups (bivalves, cephalopods, crustaceans, and fish) and assess their variations in terms of ecological and geographical factors. We analyzed organs (brain, digestive gland, gills, gonads, kidneys, liver, and muscles) and whole organisms of 33 
species from three climatically contrasted zones (tropical: New Caledonia; temperate: Bay of Biscay; subantarctic: Kerguelen Islands).

\section{Materials and methods}

\subsection{Sampling}

For our analyses, we selected 33 species from three distinct biogeographic areas: the Bay of Biscay (northeast Atlantic Ocean), New Caledonia (western tropical Pacific Ocean), and the Kerguelen Islands (southern Indian Ocean; see Supplementary $\because \mathrm{g} . \mathrm{S} 1$ ). These areas were chosen to explore the effect of climate on Li bioaccumulation in m. rin represents a temperate system, New Caledonia a tropical $\ldots$ stem, and the Kerguelen Islands a subpolar environment. Species were carefully selectc ' to se comparable across the biogeographic areas in terms of taxonomy, position in the wate cr,limn (habitat), and trophic ecology.

Samples from the Bay of Biscay w re ' ought from fishermen at the local seafood market in La Rochelle (France) between Octoier 2018 and March 2019. Pelagic organisms from the Kerguelen Islands were collected on ro ises of the RV "La Curieuse" in February 1998 (austral summer) with a IYGPT trawl Inı "national Young Gadoid Pelagic Trawl, opening $12 \times 7 \mathrm{~m}^{2}$ ) with $10 \mathrm{~mm}$ mesh size in th co'le, while benthic fish were collected from net fishing at the same period. Samples from Ne.' ' 'aledonia were collected in March and October 2007. The samples from Kerguelen and New Caledonia were gathered from a former laboratory collection and have been the subject of several previous studies focusing on other trace elements (Bustamante et al., 2003; Chouvelon et al., 2008; Cipro et al., 2018; Metian et al., 2013). The analyzed organisms included molluscs (bivalves and cephalopods), crustaceans (Malacostraca), and fish (Chondrichthyes and Actinopterygii). The organisms were divided into trophic groups to assess the influence of food and feeding ecology characteristics on Li bioaccumulation (Metian et al., 2013; Cipro et al. 2018). We defined the trophic groups according to feeding mode (filterfeeders, grazers/scavengers, predators) and preferred predator diet (i.e., invertebrates, small fish, 
or both). In addition, the trophic level of each fish species (Froese and Pauly, 2020) was used to better define any relationship between an organism's Li content and its position in the food webs. These trophic levels are based on the organism diet and the trophic level of their food items. They are estimated using nitrogen isotopes $\left(\delta^{15} \mathrm{~N}\right)$ to quantitatively position species in their respective food webs (Kline and Pauly, 1998).

Immediately after sampling, all organisms were weighed (wet weight, ww) and measured (total length, i.e., from the head to the base of the caudal fork for fish, mantle length for squids, shell width for bivalves, and carapace length for some crus act ns). The collected species and their weights (wet and dry) and lengths are reported it Su plementary Table S1. Fish were dissected in a clean laboratory to sample the dors $₫$ 1. uscle, liver, kidneys, gills, and brain. Dissected organs of the king scallop Pecten maximu, wert the adductor muscle, gonads, digestive gland, and gills, whereas only the muscles anc' gonads of the glory scallop Mimachlamys gloriosa were collected. Whole Pacific oysters Cras ostrea gigas from two brands, "Fines de Claires" and "Spéciales", from the Bay of Biscav -vers analyzed. Muscles from the blue shrimp Litopenaeus stylirostris and the European spicer rab Maja brachydactyla were sorted. Cephalopod digestive glands were analyzed too (e: $\mathrm{e}_{\mathrm{K}}$ - for S. officinalis and L. vulgaris). In addition to the digestive gland, only the mantle m as ${ }^{\top} \mathrm{e}$ was collected for the broadclub cuttlefish Sepia latimanus and the oval squid Sepioteuthis ı ssoniana, whereas remaining tissues (mantle muscle, gut, head, arms, and skin) were merged for the flying squid Todarodes cf. angolensis and the greater hooked squid Moroteuthopsis ingens. Tissue samples were stored in clean individual plastic bags, freshweighed (ww), and put at $-20^{\circ} \mathrm{C}$ until being freeze-dried during $48 \mathrm{~h}$. After drying, samples were again weighed (dry weight, dw), ground to a fine powder with a porcelain mortar and pestle, and stored in clean individual plastic vials.

2.2. Sample dissolution and Li concentration analyses 
To minimize procedural blanks, the following procedures were performed in a pressurized clean laboratory, under a fume hood, and using distilled reagents and pre-cleaned vessels. Between 200- and 250-mg aliquots of each freeze-dried tissue sample were weighed and poured into a Corning® $50 \mathrm{~mL}$ centrifuge tube. Sample dissolution was performed overnight at room temperature in a mixture of $6 \mathrm{~mL}$ of $65 \%$ ultrapure $\mathrm{HNO}_{3}$ and $2 \mathrm{~mL}$ of $37 \%$ ultrapure $\mathrm{HCl}$ (reverse aqua regia). For mineralization, the dissolved samples were transferred to a microwave and heated to $120^{\circ} \mathrm{C}$ over $30 \mathrm{~min}$, then held at $120^{\circ} \mathrm{C}$ for $15 \mathrm{~min}$. After mineralization, all samples were diluted to $50 \mathrm{~mL}$ with Milli-Q water. Procedural hla. $\mathrm{ks}$ and the reference material IAEA 436 (tuna fish flesh; International Atomic Energy f.gc. cy, Austria) were prepared via the same protocol to evaluate contamination and data precicic. and accuracy.

Li concentrations were analyzed using a Theimo ıisher X-Series II Inductively Coupled Plasma Mass Spectrometer. Li concentratioi are reported in $\mu \mathrm{g} / \mathrm{g} \mathrm{dw}$. Calibration and spike solutions were prepared using a $1,000 \mathrm{ng} / \mathrm{L} \mathrm{Li}$ monoelemental commercial solution. The biological reference material IAEA 430 was analyzed several times during each analytical session to monitor the accuracy an' reproducibility of the measured $\mathrm{Li}$ concentrations; the Li concentration of this biologic $\urcorner 1 \_$ference material is not certified, but was estimated by Azemard et al., $2006\left(0.040 \pm 0.0^{\prime}\right.$ נy, 'g/g dw, confidence interval from 0.018 to $\left.0.062 \mu \mathrm{g} / \mathrm{g} \mathrm{dw}\right)$. Due to the uncertainties on the $\mathrm{L}^{\cdot}$ concentration of this standard, we developed a spike-addition method to verify (1) the accuracy of our Li measurements and (2) the completeness of the mineralization process. For each of the twelve mineralization sessions, four aliquots of $\sim 250 \mathrm{mg}$ of IAEA 436 were digested. In three of these tubes, spikes of different Li concentrations $(0.5,1.0$, or $5.0 \mu \mathrm{g} / \mathrm{L})$ were added. We achieved good recovery rates for the spike concentrations $(98.2 \pm 3.4 \%, n=12)$, demonstrating the near-100\% yield of our entire chemical procedure. The calibration solutions were run several times during each analytical session to monitor instrumental drift and correct for the memory effect. Blank contributions were about 5\%, and internal errors on measurements 
were $2 \%$. Non-spiked IAEA 436 reference material provided good reproducibility (4\%) between the twelve analytical sessions, and a mean Li concentration of $0.020 \pm 0.001 \mu \mathrm{g} / \mathrm{g} \mathrm{dw}(n=12)$, within the confidence interval published by Azemard et al., 2006. During our analytical sessions, the detection limit was $0.0125 \mu \mathrm{g} / \mathrm{g} \mathrm{dw}$ for $250 \mathrm{mg}$ of sample taken up in $50 \mathrm{~mL}$ of diluted reverse aqua regia; only two samples had concentrations below this value and were sidelined: the liver of Scyliorhinus canicula and the brain of Spondyliosoma cantharus.

\subsection{Statistical data processing}

As the Li concentrations in our samples are not norn ally distributed, even transformed, differences among data groups (i.e., between biogeoglap areas, taxonomic groups, trophic groups and levels, habitat, and organs) were tested $\_$atis ically using the $\mathrm{R}$ software package (R Core Team, 2017) following two non-parame ar tests: the Mann-Whitney-Wilcoxon test for comparisons between two data series, and $\mathbf{u} \geq \mathbf{n}$ iskal-Wallis test for comparisons between three or more series. The level of significance for tatistical analyses was set at $\alpha=0.05$. The detailed statistical treatment is presented in $\mathrm{t}^{\mathrm{t}} \mathrm{e}, \mathrm{n}$.

The relationships betwe $\mathrm{A}$ Li concentrations and biological parameters were investigated using multiple correspondeı e a nalyses (MCA, see section 3.1), a statistical tool that reduces the

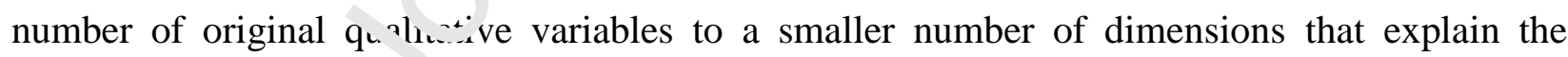
majority of the observed variability. In this study, MCA was performed in R considering the following variables: habitat, location, trophic group, taxonomical group, and organ type (predictor categorical variables); Li concentration was then added as a single dependent quantitative variable. We used the "ACM" function of "FactoMineR" R package (quanti.sup subfunction was filled to take $\mathrm{Li}$ into account).

\section{Results and Discussion}


Li concentrations ranged from the detection limit $(0.01 \mu \mathrm{g} / \mathrm{g} \mathrm{dw})$ to $1.20 \mu \mathrm{g} / \mathrm{g} \mathrm{dw}$ (digestive gland of Pecten maximus) (Supplementary Table S2). As the oceanic Li concentration is homogeneous at $0.18 \mu \mathrm{g} / \mathrm{mL}$ (Aral and Vecchio-Sadus, 2011; Misra and Froelich, 2012; Riley and Tengudai, 1964), the large range of Li concentrations observed in marine organisms must result from different bioaccumulation dynamics related to biotic and abiotic processes. To investigate this, we first examine the entire dataset to identify which factors are related to high or low - Li concentrations, and then investigate these factors in more details.

\subsection{Multifactorial control of Li bioaccumulation by mar ne . pecies}

The relationship between $\mathrm{Li}$ and biological $\mathrm{n} \mathrm{tra}^{2}$-cers (modalities of the predicted categorical variables) was investigated using MCA, 's di scribed in section 2.3. In Figure 1, the calculated coordinates of all variable modalites are plotted in a two-dimensions space. Li concentration was added as a quantitativ $-a_{1}$ hle, and is represented by the grey arrow. The proximity between different modalities in $\mathrm{Fl}_{\mathrm{o}}$ are 1 indicates a connection between them, such as for "bivalves" and "filter-feeders", c c "

It is notable that the mrdalı: es "fish", "predators of invertebrates", "predators of small fish", and "demersal" are as.nci tted (group 1, Fig. 1), which was expected considering that most fish are demersal. "b: $\mathbf{b}_{1}$, „," "benthic", and "filter-feeders" form a second group (group 2), which is consistent with the fact that collected filter-feeders are benthic bivalves. "Cephalopods" are associated with "pelagic" and "predators of invertebrates and small fish" in group 3, as this group is represented by four pelagic squid $v s$. only two species of benthic cuttlefish. "Crustaceans" and "grazers/scavengers" constitute group 4. The association of these two last modalities is also related to sampling: the only collected grazer is a crustacean. Each group includes several parameters (biogeographic area, trophic group, taxonomy, habitat, or tissue), indicating that most of the modalities are confounded. There is clearly an imbalance across potential predictors that is related to the sampled organisms. However, sampling location is 
reasonably well crossed with other predictors and it is possible to evaluate independent effects of this variable (see section 3.2).

The Li concentration trend (grey arrow) points almost directly towards group 2 and away from group 1, indicating that samples whose modalities belong to those groups 2 and 1 correspond to high and low $\mathrm{Li}$ concentrations, respectively. Whether feeding mode (filterfeeding) or taxonomy (bivalve) is related to high Li values cannot be discerned with this data set, however, the MCA shows that filter feeding bivalves displa! higher Li values. The impact of each variable on Li concentration is further discussed in the fr ilo ring sections.

\subsection{Impact of biogeographic area}

To determine whether Li concentration differs a urding to biogeographic areas, we chose three locations characterized by contrasted clin ies and environments, here represented by the annual mean sea surface temperature $(\mathrm{S}, \mathrm{T})$ New Caledonia $\left(\mathrm{SST}=21^{\circ} \mathrm{C}\right)$, the Bay of Biscay $\left(\mathrm{SST}=16^{\circ} \mathrm{C}\right)$, and the Kerguelen Isla. $\cdot \mathrm{ds}\left(\mathrm{SST}=1{ }^{\circ} \mathrm{C}\right)(\mathrm{https} / / / \mathrm{www}$.watertemperature.org/).

For comparing Li concentri.u $\eta_{\text {s }}$ of similar tissues, we choose muscle, the only ubiquitous organ among the various stu tied organisms (note that gonads from Pectinidae are also considered, since gonads $\cdots \mathrm{a}$..u uscle were pooled together in New Caledonian individuals). At first glance, the observe ' differences in Li concentrations between biogeographic areas are not drastic, as shown in Figure 2 and Supplementary Table S3. The largest difference (of $0.17 \mu \mathrm{g} / \mathrm{g}$ $\mathrm{dw}, p<0.01)$ is observed between Li concentrations in crustacean muscles from the Bay of Biscay and New Caledonia. For fish and cephalopod muscles, differences between biogeographic areas are less than $0.06 \mu \mathrm{g} / \mathrm{g} \mathrm{dw}$ (on average). Li concentrations in muscles and gonads of Pectinidae from the Bay of Biscay are similar to or slightly lower than those of Pectinidae from New Caledonia. In the MCA, the predicted variable "Location" is not highly confounded with other variables (cf. Fig. 1 section 3.1), allowing discussion on its direct effect on Li 
concentrations. The modalities "Bay of Biscay", "Kerguelen Islands", and "New Caledonia" are not aligned with observed variations in Li concentrations (Fig. 1), indicating that, considering all species, there is no clear and simple relationship between tissue Li concentrations and a biogeographic / climatic gradient. The similar Li concentrations in Pectinidae are also consistent with the results of Chassard-Bouchaud et al. (1984), which showed that Li retention by Mytilus edulis (common mussel) is geographically independent.

Nevertheless, in fish, $\mathrm{Li}$ concentrations in muscles ( $n>20$ per location) increase significantly $(p<0.0001)$ from $0.03 \pm 0.01 \mu \mathrm{g} / \mathrm{g} \mathrm{dw}$ (New Caı donia) to $0.14 \pm 0.17 \mu \mathrm{g} / \mathrm{g} \mathrm{dw}$ (Kerguelen Islands) with decreasing SST, similar to crusta ear s (although we have fewer data on crustaceans) (Fig. 2). The fish, as poikilotherms, art nietabolically influenced by seawater temperature: typically, lower temperatures mean siower metabolism (Mehta, 2017). Therefore, the higher Li concentrations in muscles of fi ' from the Kerguelen Islands are consistent with a slower Li turnover (and therefore a highe, $\mathrm{i}$ i retention time), compared to fish from the Bay of Biscay and New Caledonia. This tre-r 1s not observed for cephalopods, but we only had a few samples from New Caledonia ( $\mathrm{n}=\boldsymbol{\gamma}$, It is consistent with the temperature effect on $\mathrm{Hg}$ and $\mathrm{Pb}$ retention in in the black-lip cvss $\mathbf{r}$ Saccostrea echinata (Denton and Burdon-Jones, 1981), with increasing metal half-life in visceral mass when temperature decreases. Accumulation and depuration experiments if $\mathrm{Cu}$ and $\mathrm{Pb}$ conducted on the girdled horn sea snail Cerithidea cingulata and the Starry flounder Platichthys stellatus, respectively, also reported higher tissue concentrations after depuration at low temperature compared to higher temperatures (Prabhakara Rao et al., 1988; Varanasi, 1978). A more detailed investigation of Li bioaccumulation processes is however necessary to explore the relationship between Li concentrations and metabolic rate among different species. 
Collected organisms allow exploring Li accumulation in different trophic groups (detailed in section 2.1). Considering all tissues, Li concentration among all filter-feeders is $0.42 \pm 0.25$ $\mu \mathrm{g} / \mathrm{g} \mathrm{dw}$, a value significantly higher than for any other trophic groups $(p<0.0001$; Fig. 3). In contrast, $\mathrm{Li}$ concentrations in grazers/scavengers and in predators of invertebrates, of invertebrates and small fish, and of small fish are low $(0.10 \pm 0.02,0.10 \pm 0.11,0.09 \pm 0.07$, and $0.07 \pm 0.00 \mu \mathrm{g} / \mathrm{g} \mathrm{dw}$, respectively) and not statistically different $(p>0.05)$. These differences are in agreement with our MCA results (section 3.1) indicating that Li concentrations align from the modality "predators of small fish" towards the modality "filter-feec'rs".

Considering muscle tissues alone avoids potential bia due to the incorporation of Lienriched sedimentary particles in the gut, for instanc, $11 \mathrm{t}$ the digestive gland of filter-feeders (see section 3.4). Muscle tissues display the same tre 1 d beiween filter-feeders and other trophic groups (Fig. 3B), although not significant du to the paucity of muscles sampled among filterfeeders $(n=10)$.

The same Li decrease along tr $\mathrm{p}^{\prime} \mathrm{i}^{-}$- groups and among taxonomic groups is observed in the three biogeographic areas (Fig. S3). All areas combined, Li concentrations decrease from bivalves to fish $(p<0.05)$ as: b: ralves $(0.42 \pm 0.50 \mu \mathrm{g} / \mathrm{g} \mathrm{dw})>$ crustaceans $(0.19 \pm 0.19 \mu \mathrm{g} / \mathrm{g} \mathrm{dw})$ > cephalopods $(0.12+0.10 \mu \mathrm{g} / \mathrm{g} \mathrm{dw})>$ fish $(0.08 \pm 0.17 \mu \mathrm{g} / \mathrm{g} \mathrm{dw}$; Fig. 4$)$. The variability among Li concentrations was li.nited, except for fish $(0.01-0.77 \mu \mathrm{g} / \mathrm{g} \mathrm{dw})$ and, to a lesser extent, cephalopods $(0.02-0.23 \mu \mathrm{g} / \mathrm{g} \mathrm{dw})$, as previously reported for other trace elements (e.g., Rainbow 2002). This variability may partly be explained by the various habitats (benthic, demersal, and pelagic) occupied by species within these two groups. However, sampled organisms did not show a significant effect of habitats on Li concentrations. In contrast, the MCA (Fig. 1) indicates that the benthic habitat is close to the high $\mathrm{Li}$ concentration group (group 2). This is strongly influenced by the dominance of Li-rich filter-feeders among benthic species, whose Li enrichment in the digestive gland is discussed in more details in the following section. The Li 
concentration variability within groups can also be related to the presence of various tissues (see section 3.4), and result from species differences in ecological need, swimming behavior, or metabolic activities (Canli and Atli, 2003).

Since filters-feeders are generally at lower trophic levels than predatory fish, our results strongly suggest that trophic ecology influences Li concentrations in marine organisms, but a bioreduction, not biomagnification, of $\mathrm{Li}$ is observed along the trophic webs (Fig. 3A). Both comparisons including all organs (Figs. 3A, 4) and muscler only (Fig. 3B) demonstrate the consistent bio-reduction of $\mathrm{Li}$ along marine food webs, sim $\mathrm{ar}$ o that previously described for the two essential trace metals, $\mathrm{Cu}$ and $\mathrm{Zn}$. In contrast, $\mathrm{H}_{\ulcorner} \mathrm{r}$ is known to significantly bioamplify towards the top of the food webs (Atwell et al., 1998\% C nnsensus has not been reached on other elements such as As, Cd, and Se, although severas stucies argue for their bioamplification in specific cases (Barwick and Maher, 2003: Г haman et al., 2012; see review in Suedel at al., 1994). These observations suggest that $l_{1}-$ risk assessment on human health is limited to Li intake from shellfish consumptior ans not from Li-poor mesopredators (e.g. fish and cephalopods), which is in marke $\mathrm{d}$ ( $n$ ntrast to $\mathrm{Hg}$ (Atwell et al., 1998; Chouvelon et al., 2012; Lavoie et al., 2013).

\subsection{Li distribu tion in the tissues of marine organisms}

Our dataset allows us to further explore the internal distribution and accumulation of $\mathrm{Li}$ among various organs. Comparison of the different tissues within each taxonomic group (Fig. 5, Table 1; excluding crustaceans, for which only muscles were analysed) shows that cephalopods are the only group for which there is no significant difference $(p>0.05)$ between $\mathrm{Li}$ concentrations in muscles and digestive gland. For the other groups, Li is unequally distributed among organs (Fig. 5, Table 1). In fish, Li is most concentrated in the gills, moderately concentrated in the kidneys and brain, and least concentrated in the liver and muscles. In bivalves (P. maximus), both gills and digestive gland display high Li concentrations compared to muscles 
and gonads. These observations are supported by the MCA results (section 3.1): the Li trend extends from the modalities "liver", "brain", "muscles", and "kidneys" towards "gills" and "gonads" in the high Li concentration group (group 2; Fig. 1).

In fish, the liver is usually reported to be a storage organ for many trace elements $(\mathrm{Cd}, \mathrm{Cu}$, $\mathrm{Fe}, \mathrm{Hg}, \mathrm{Pb}$, and $\mathrm{Zn}$; Metian et al., 2013). However, our data show that the liver is depleted in $\mathrm{Li}$ compared to the gills and kidneys (Figs. 5, 6), regardless of geographic origin (Table S2). Nonetheless, liver Li concentrations are higher than those in muscles, except for $S$. canicula and C. gunnari (Fig. 6, Table S2). The relatively low Li concent atı $n$ s in fish liver (average $0.07 \pm$ $0.03 \mu \mathrm{g} / \mathrm{g} \mathrm{dw}$ ) demonstrate that $\mathrm{Li}$ is not stored in this o gan our results instead show that the brain, gills, and kidneys play a key role in Li bioaccu ul $_{1}$ tion. The kidneys and gills are involved in ionoregulation, and brain functions mostly denend on $1 \mathrm{Ja}$ channels that areable to transport $\mathrm{Li}$ as well. Gills are in direct contact with seaw ter and, together with the kidneys, play a critical role in osmoregulation of marine organis, is and the maintenance of their internal Na balance (Greenwell et al., 2003). Li uptake ir fisı most likely occurs through Na channels (Tkatcheva et $a l ., 2007)$ and ubiquitous Na-H Exci angers (NHEs) located in cell membranes (Counillon et al., 2016). $\mathrm{Li}^{+}$ions can penetrate ${ }_{\llcorner}$ilı ells via NHEs by following $\mathrm{Na}^{+}$pathways (Milosavljevic et al., 2014; Tkatcheva et al., ? $\boldsymbol{u}^{7}$ ). The high Li concentrations measured in gills and kidneys is thus consistent with Li accumı lation primarily controlled by NHEs during water filtration, explaining why these two organs appear crucial to Li distribution in marine organisms. This implies that seawater is likely a major pathway of $\mathrm{Li}$ incorporation, although additional particulate pathways, such as predation, might participate to $\mathrm{Li}$ incorporation. Future studies should now further investigate the relative importance of different Li incorporation pathways in fish.

Gills functions may also partly explain the observed Li bio-reduction between filterfeeders and other trophic groups (cf. section 3.3). Indeed, Li becomes more concentrated in the muscles of organisms that use gills both for respiration and feeding (e.g., filter-feeders) compared 
to organisms that use gills for respiration only (crustaceans, cephalopods, and fish). Thus, organ function may play a key role in how Li is distributed and internally regulated. Unfortunately, gills from filter-feeders could not be further analyzed to investigate this relationship. Among fish, aside from muscles, we observe no trend according to trophic groups for Li concentrations in liver, kidneys, or gills (Fig. S4). However, we note that Li concentrations in fish brain increase with trophic level (from 3 to 5, $p<0.01$, Fig. 7), a trend deserving further investigation.

In the king scallop Pecten maximus, the highest $\mathrm{Li}$ cnncentration was observed in the digestive gland $(0.80 \pm 0.27 \mu \mathrm{g} / \mathrm{g} \mathrm{dw}$, Fig. 6), apparently co ssistent with its major role in detoxification and the storage of several trace elements, s ich is $\mathrm{Ag}, \mathrm{As}, \mathrm{Cd}, \mathrm{Cu}$, and $\mathrm{Zn}$, which reach high concentrations in this tissue (Bustamante ani Miiramand, 2005; Metian et al., 2008a, b; Saavedra et al., 2008). Nevertheless, the considered rectinidae live in benthic sediments and are likely to ingest fine particles from the ri: iddy sand, such as silts and clays (Mikulich and Tsikhon-Lukamina, 1981; Shumway et aı. 1987), which can contain Li at concentrations >100 $\mu \mathrm{g} / \mathrm{g}$ (Tardy et al., 1972), several ra rs of magnitude above that dissolved in seawater. Therefore, the high digestive gli na ${ }_{1}$ concentrations may be due to the presence of sediment particles that remained in the ou nortions sampled with the digestive gland tissue, as the Pecten were not depurated befor - us section. This interpretation is consistent with the presence of Li-rich particles observed by $\mathrm{Ch}_{\mathrm{c}}$ ssard-Bouchaud et al. (1984) in the intestine lumen of the pearl oyster Pinctada fucata martensi. Similarly, the Li concentrations in gonads may be overestimated as this organ is crossed by the intestine, which serves also for gamete emission (Fig. 6). Although not evidenced yet, $\mathrm{Li}^{+}$ions from the ingested food and sediment particles may pass through the intestine to be stored in the digestive gland and gonads, as suggested for the blue mussel (Mytilus edulis) and the transparent razor shell (Cultellus pellucidus) (Chassard-Bouchaud et al., 1984).

\section{Conclusions}


This work provides the first extensive dataset of $\mathrm{Li}$ concentrations and distributions among marine organisms and their tissues in contrasted biogeographic areas (the Bay of Biscay, New Caledonia, and the Kerguelen Islands). A statistical linear model demonstrates that each of the studied variables (habitat, location, trophic group, taxonomic group, and organ type) contributes to the observed variability in Li concentrations. Within trophic webs, Li is consistently bioreduced in the three regions. Li heterogeneities among organs are consistent with the biological incorporation of Li by $\mathrm{Na}$ transporters. Although further study is required at high trophic levels, the observed Li bio-reduction towards predators suggests a werk 1 ' pact of their consumption on human health. However, this investigation also highlights .nc need to assess Li bio-accumulation in bivalves and shellfish and their potential impact on hnı ^n health in case of Li contamination.

\section{Acknowledgments}

We acknowledge financial support fror. .'e . 1 NR ISO2MET (//anr.fr/Projet-ANR-18-CE340002, www.iso2met-project.fr/) and we ar grateful for access to facilities provided by the laboratory LIttoral ENvironnement $\sharp t$ s crétés (LIENSs). This work benefited from the support

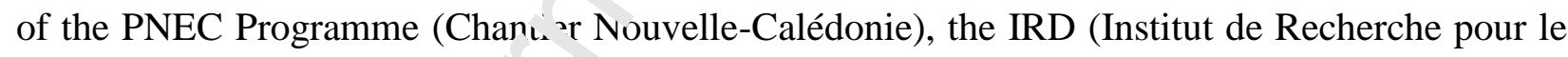
Développement), the IPEV (1. ctitut Paul Emile Victor, program 309, C. Barbraud), and the TAAF (Terres Australe: et Antarctiques Françaises). The authors are grateful to O. Pringault (IRD-Nouméa) for his hr.p in organizing the fieldwork in New Caledonia, and to Captain M. Clarque (IRD-Nouméa) and the IRD Diver Team for providing access to their diving equipment. We thank G. Duhamel and the crew of the $R V$ 'La Curieuse' for their help with collecting organisms in the Kerguelen Islands. We thank Michel Warnau for his support during fieldwork in New Caledonia, and Maud Brault-Favrou and Elise Noger-Huet for their help during sample preparation. We are also extremely grateful to Jean-Olivier Irisson (LOV) for his help with statistical computation of the data (linear model and MCA). We thank the CPER (Contrat de Projet Etat-Région) and the FEDER (Fonds Européen de Développement Régional) for funding 
ICP-MS analyses at the LIENSs laboratory. The IUF (Institut Universitaire de France) is acknowledged for its support to PB as a Senior Member.

\section{Author contributions}

PB and NV led the project. TLL, PB, LW, and YC participated in sampling. CC and LW performed sample preparation and Li concentration measurements. FT and LW modeled the data and wrote the manuscript. All authors contributed to interpretation and manuscript correction.

\section{References}

Ansari, T. M., Marr, I. L., Tariq, N., 2004. Heavy meta'? in Inarine pollution perspective-a mini review. J. Appl. Sci. 4, 1-20.

Aral, H., Vecchio-Sadus, A., 2008. Toxicit $/$ ur ithium to humans and the environment-A literature review. Ecotox. Environ. Safe. i’ 3), 349-356.

Aral, H., Vecchio-Sadus, A., 201 'ithium: environmental pollution and health effects. Encyclopedia of Environmental i. aaltn, 628-636.

Atwell, L., Hobson, K.A. W`1ª, H.E., 1998. Biomagnification and bioaccumulation of mercury in an arctic marine fooc veo: insights from stable nitrogen isotope analysis. Can. J. Fish. Aquat. Sci. 55, 1114-1121.

Azemard, S., de Mora, S.J., Guitart, C., Wyse, E., 2006. Report on the world-wide intercomparison exercise for the determination of trace elements and methylmercury in fish homogenate IAEA-436. IAEA/AL/157, IAEA/MEL/77, IAEA, 1-104. 
Barwick, M., Maher, W., 2003. Biotransference and biomagnification of selenium copper, cadmium, zinc, arsenic and lead in a temperate seagrass ecosystem from Lake Macquarie Estuary, NSW, Australia. Mar. Environ. Res. 56, 471-502

Bryan, G. W., 1979. Bioaccumulation of marine pollutants. Philos. T. R. Soc. Lond. 286(1015), $483-505$.

Bustamante, P., Miramand, P., 2005. Subcellular and body distributions of 17 trace elements in the variegated scallop Chlamys varia from the French coast oi the Bay of Biscay. Sci. Total Environ. 337, 59-73.

Bustamante, P., Bocher, P., Cherel, Y., Miramand, ૨., Taurant, F., 2003. Distribution of trace elements in the tissues of benthic and pelagic fish frum the Kerguelen Islands. Sci. Total Environ. 313(1-3), 25-39.

Canli, M., Atli, G., 2003. The relatio`ships between heavy metal (Cd, Cr, Cu, Fe, Pb, Zn) levels and the size of six Mediterranean fis.ı pi cies. Environ. Pollut. 121, 129-136.

Chan, L. H., Leeman, W. P., Plank, T., 2006. Lithium isotopic composition of marine sediments. Geochem. Geophy. Geos:. ${ }^{7}($ ).

Chassard-Bouchaud, C., 'jalle, P., Escaig, F., Miyawaki, M., 1984. Bioaccumulation of lithium by marine organisms in European, American, and Asian coastal zones: microanalytic study using secondary ion emission. C. R. Acad. Sci. Paris, Serie III. 299(18), 719-724.

Choi, H-B., Ryu, J-S., Shin W-J., Vigier, N., 2019. The impact of anthropogenic inputs on lithium content in river and tap water. Nat. Commun. 10, 5371-5378. 
Chouvelon, T., Warnau, M., Churlaud, C., Bustamante, P., 2008. Hg concentrations and related risk assessment in coral reef crustaceans, molluscs and fish from New Caledonia. Environ. Pollut. 157(1), 331-340.

Chouvelon, T., Spitz, J., Caurant, F., Mendez-Fernandez, P., Autier, J., Lassus-Débat, Z., Chappuis, A., Bustamante, P., 2012. Enhanced bioaccumulation of mercury in deep-sea fauna from the Bay of Biscay (north-east Atlantic) in relation to trophic positions identified by analysis of carbon and nitrogen stable isotopes. Deep-Sea Res. 65, 113-17.4.

Cipro, C. V. Z., Cherel, Y., Bocher, P., Caurant, F., Mirar nu, P., Bustamante, P., 2018. Trace elements in invertebrates and fish from Kerguelen waı 'rs, southern Indian Ocean. Polar Biol. 41(1), 175-191.

Counillon, L., Bouret, Y., Marchiq, I., Pnu s ségur, J., 2016. Na+/H+ antiporter (NHE1) and lactate/H+ symporters (MCTs) in $\mathrm{pH}$ hon ^ stasis and cancer metabolism. BBA-Mol. Cell. Res. 1863(10), 2465-2480.

Decarreau, A., Vigier, N., Pálk svà, H., Petit, S., Vieillard, P., Fontaine, C., 2012. Partitioning of lithium between smectite and sı.ution: An experimental approach. Geochimc. Cosmochim. Ac. $85,314-325$.

Denton, G.R.W., Burdon-Jones, C., 1981. Influence of temperature and salinity on the uptake, distribution and depuration of mercury, cadmium and lead by the black-lip oyster Saccostrea echinata. Mar. Biol. 64, 317-326.

Eisler, R., 2010. Compendium of trace metals and marine biota Volume 2 vertebrates. Elsevier publications, Vol. 1, 1-512. 
English, M. D., Robertson, G. J., Mallory, M. L., 2015. Trace element and stable isotope analysis of fourteen species of marine invertebrates from the Bay of Fundy, Canada. Mar. Pollut. Bull. 101(1), 466-472.

Froese, R. D. Pauly., 2020. FishBase. World Wide Web electronic publication. www.fishbase.org, version (03/2020).

Giotakos, O., Nisianakis, P., Tsouvelas, G., Giakalou, V. V., 2013. Lithium in the public water supply and suicide mortality in Greece. Biol. Trace Elem. Res. 1sé(1-3), 376-379.

Greenwell, M. G., Sherrill, J., Clayton, L. A., 2003. Os, nor gulation in fish: Mechanisms and clinical implications. Vet. Clin. North Am. Exot. Ani 1. 1 ract. 6 (1), 169-189.

Guérin, T., Leblanc, J.-C., Noël, L., Chekri, R, Tirot, V., Vastel, C., Volatier, J.-L., 2011. Determination of 20 trace elements in ssh anc other seafood from the French market. Food Chem. 127(3), 934-942.

Hall, T.S., 1942. The mode of act'v' ô ithium salts in amphibian development. J. Exp. Zool. 89, $1-35$.

Harper, G., Sommervill ?. R, Kendrick, E., Driscoll, L., Slater, P., Stolkin, R., Walton, A., Christensen, P., Heidric ${ }^{h}$, O., Lambert, S., Abbott, A., Ryder, K., Gaines, L., Anderson, P., 2019. Recycling lithium-ion batteries from electric vehicles. Nature. 575, 75-85.

Huh, Y., Chan L-H., Zhang, L., Edmond, J., 1998. Lithium and its isotopes in major world rivers: Implications for weathering and the oceanic budget. Geochim. Cosmochim. Ac. 62, 2039-2051.

Kao, K.R., Masui Y., Elinson, R.P., 1986. Lithium-induced respecification of pattern in Xenopus laevis embryos. Nature. 322, 371-273. 
Kelly, B., Ikonomou, M., Blair, J., Morin, A., Gobas, F., 2007. Food Web-Specific Biomagnification of Persistent Organic Pollutants. Science. 317, 236-239.

Kiyomoto, M., Morinaga, S., Ooi, N., 2010. Distinct embryotoxic effects of lithium appeared in a new assessment model of the sea urchin: the whole embryo assay and the blastomere culture assay. Ecotoxicology. 19, 563-570.

Kline, T.C., Pauly, D., 1998. Cross-validation of trophic level estimates from a mass-balance model of Prince William Sound using 15N /14N data. In Fisi-ary stock assessment models. ASGP. AK-SG-98-01.

Kszos, L. A., Stewart, A. J., 2003. Review of lithium in he aquatic environment: Distribution in the United States, toxicity and case example of groundwater contamination. Ecotoxicology. $12(5), 439-447$.

Labbé, J. F., Daw, G., 2012. Panora ^a 2011 du marché du lithium. Rapport Public BRGM, 1154.

Lavoie, R.A., Jardine, TD., Chumchal, M.M., Kidd, K.A. Campbell, L.M., 2013. Biomagnification of Mer... in Aquatic Food Webs: A Worldwide Meta-Analysis. Envir. Sci. Tech. Lib. 47, 13385-1 5`94.

Leguérinel, M., Lefebvre, G., Christmann P., 2018. Compétition entre secteurs industriels pour l'accès aux matières premières. COMES seminar.

Liaugaudaite, V., Mickuviene, N., Raskauskiene, N., Naginiene, R., Sher, L., 2017. Lithium levels in the public drinking water supply and risk of suicide: A pilot study. J. Trace Elem. Med. Bio. 43, 197-201. 
Luoma, S. N., 1983. Bioavailability of trace metals to aquatic organisms - A review. Sci. Total Environ. 28(1-3), 1-22.

Machado-Vieira, R., 2018. Lithium, stress, and resilience in bipolar disorder: Deciphering this key homeostatic synaptic plasticity regulator. J. Affect. Disorders. 233, 92-99.

Mehta, K., 2017. Impact of temperature on contaminants toxicity in fish fauna: a review. Indian J. Sci. Technol. 10(18), 1-6.

Metian, M., Bustamante, P., Hédouin, L., Warnau, M., 2008 ı. A cumulation of nine metals and one metalloid in the tropical scallop Comptopallium radı ${ }^{\prime} a$ f $\mathrm{j}$ om coral reefs in New Caledonia. Environ. Pollut. 152, 543-552.

Metian, M., Bustamante, P., Cosson, R.P., Héd ' u’n, L., Warnau, M., 2008b. Investigation of Ag in the king scallop Pecten maximus usi ıg iela and laboratory approaches. J. Exo. Mar. Biol. Ecol. 367, 53-60.

Metian, M., Warnau, M., Chouve'vi ¿., Pedraza, F., Rodriguez y Baena, A. M., Bustamante, P., 2013. Trace element bioaccun. ${ }^{1}$ ation in reef fish from New Caledonia: Influence of trophic groups and risk assessmer:. $f_{\rho_{1}}$ _onsumers. Mar. Environ. Res. 87-88, 26-36.

Mikulich, L.V., Tsikho: 'Lukamina, A., 1981. Food of the scallop. Oceanology+, 21, 633-635.

Millot, R., Petelet-Giraud, E., Guerrot, C., Négrel, P., 2010. Multi-isotopic composition ( $\delta 7 \mathrm{Li}-$ $\delta 11 \mathrm{~B}-\delta \mathrm{D}-\delta 18 \mathrm{O})$ of rainwaters in France: Origin and spatio-temporal characterization. Appl. Geochem. 25 (10), 1510-1524.

Milosavljevic, N., Monet, M., Léna, I., Brau, F., Lacas-Gervais, S., Feliciangeli, S., Counillon, L., Poët, M., 2014. The intracellular Na+/H+ exchanger NHE7 effects a Na+ coupled, but not K+ coupled proton-loading mechanism in endocytosis. Cell Rep. 7(3), 689-696. 
Misra, S., Froelich, P. N., 2012. Lithium isotope history of Cenozoic seawater: Changes in silicate weathering and reverse weathering. Science. 335(6070), 818-823.

Négrel, P., Millot, R., Brenot, A., Bertin, C., 2010. Lithium isotopes as tracers of groundwater circulation in a peat land. Chem. Geol. 276 (1), 119-127.

Noël, L., Chekri, R., Millour, S., Vastel, C., Kadar, A., Sirot, V., Leblanc, J. C., Guérin, T., 2012. $\mathrm{Li}, \mathrm{Cr}, \mathrm{Mn}, \mathrm{Co}, \mathrm{Ni}, \mathrm{Cu}, \mathrm{Zn}, \mathrm{Se}$ and Mo levels in foodstuffs from the Second French TDS. Food Chem. 132, 1502-1513.

Ohgami, H., Terao, T., Shiotsuki, I., Ishii, N., Iwata, N.. '00؛. Lithium levels in drinking water and risk of suicide. Brit. J. Psychiat. 194, 464-465.

Prabhakara Rao, Y., Uma Devi, V., Prasada Iia s, D.G.V, 1988. Influence of temperature on copper accumulation and depuration in a cro icaı cerithiid Cerithidea (cerithideopsilla) cingulata (Geelin 1790). Water Air Soil Pollut. 27, 365-374

R Core Team, 2017. R: A langua oc aıu environment for statistical computing. R Foundation for Statistical Computing, Vienna, istria. URL: http://www.R-project.org.

Rahman, M.A., Hase sav a H, Lim, R.P., 2012. Bioaccumulation, biotransformation and trophic transfer of arsenicin the ${ }^{\prime}$ uatic food chain. Environ. Res. 116, 118-135.

Riley, J. P., Tongudai, M., 1964. The lithium content of sea water. Deep-Sea Res. 11(4), 563568.

Saavedra, Y., González, A., Blanco, J., 2008. Anatomical distribution of heavy metals in the scallop Pecten maximus. Food Addit. Contam. A. 25(11), 1339-1344. 
Schou, M., Amdisen, A., Trap-Jensen, J., 1968. Lithium Poisoning. Am. J. Psychiat. 125 (4), $520-527$.

Schrauzer, G. N., 2002. Lithium: Occurrence, dietary intakes, nutritional essentiality. J. Am. Coll. Nutr. 21(1), 14-21.

Schrauzer, G. N., Shrestha, K. P., 1990. Lithium in drinking water and the incidences of crimes, suicides, and arrests related to drug addictions. Biol. Trace Elem. Res. 25, 105-113.

Shumway, S., Schick, D.F., Selvin, R., 1987. Food resourc ss 1 lated to habitat in the scallop, Placopecten magellanicus (Gmelin 1791): A qualitative st 'dy. J. Shellfish Res. 6, 89-95.

Stachel, S.E., Grunwald, D.J., Myers, P.Z., 1993. Litı : יזr perturbation and goosecoid expression identify a dorsal. Development. 117, 1261-1274

Suedel, B. C., Boraczek, J. A., Peddicor' R. K., Clifford, P. A., Dillon, T. M., 1994. Trophic Transfer and Biomagnification Potentiaı of Contaminants in Aquatic Ecosystems. Rev. Environ. Contam. Toxicol. 136, 21-89.

Szklarska, D., Rzymski, P., $\left\llcorner^{\urcorner} 18\right.$. Is lithium a micronutrient? From biological activity and epidemiological obse"va i on o food fortification. Biol. Trace Elem. Res. 189, 18-27.

Tardy, Y., Krempp, G., Teauth Norbert., 1972. Le lithium dans les minéraux argileux des sédiments et des sols. Geochim. Cosmochim. Ac. 36, 397-412.

Timmer, R. T., Sands, J. M., 1999. Lithium intoxication. J. Am. Soc. Nephrol. 10, 666-674.

Tkatcheva, V., Franklin, N. M., McClelland, G. B., Smith, R. W., Holopainen, I. J., Wood, C. M. , 2007. Physiological and biochemical effects of lithium in rainbow trout. Arch. Environ. Con. Tox. 53(4), 632-638. 
U.S. Geological Survey, 2017. Mineral Commodity Summaries.

Varanasi, U., 1978. Biological fate of metals in fish. Marine biological effects of OCS petroleum development. Ed. by DA Wolfe. Boulder, Colorado, 41-53.

Won, E., Kim, Y., 2017. An oldie but goodie: Lithium in the treatment of bipolar disorder through neuroprotective and neurotrophic mechanisms. Int. J Mol. Sci. 18, 2679-2696. 
Table 1: Average Li concentrations $(\mu \mathrm{g} / \mathrm{g} \mathrm{dw} \pm \mathrm{SD})$ in various organs of bivalves, cephalopods, crustaceans, and fish from the entire dataset (Supplementary Tables S1 and S2). n: number of individuals.

\begin{tabular}{lllllllll}
\hline & Bivalves & $n$ & Cephalopods & $n$ & Crustaceans & $n$ & Fish & $n$ \\
\hline Brain & & & & & & & $0.10 \pm 0.10$ & 11 \\
Digestive gland & $0.80 \pm 0.27$ & 10 & $0.10 \pm 0.03$ & 31 & & & & \\
Gills & $0.58 \pm 0.04$ & 10 & & & & & $0.26 \pm 0.13$ & 12 \\
Gonads & $0.30 \pm 0.07$ & 10 & & & & & & \\
Kidneys & & & & & & & $0.15 \pm 0.06$ & 11 \\
Liver & & & & & & $0.07 \pm 0.03$ & 57 \\
Muscles & $0.08 \pm 0.01$ & 10 & $0.10 \pm 0.03$ & 28 & $0.19 \pm 0.10$ & 10 & $0.06 \pm 0.08$ & 163 \\
Whole individuals & $0.80 \pm 0.27$ & 25 & $0.15 \pm 0.05$ & 20 & & & & \\
\hline
\end{tabular}

Figure 1: Results of the multiple correspondence analyses (MCA $n_{\epsilon}{ }_{2}$ med over the entire dataset (Supplementary Table S2). Modality coordinates are reported ir the pace of dimensions 1 and 2 (Dim1 and Dim2), the _rst two dimensions resulting from MCA, wh: $h$ arc ordered according to the percentage of the data variability that they explain. Qualitative variabl 5 . nn idered here are trophic group, taxonomic group, habitat, organ type, and location. The grey arrow si vws Li concentration as a quantitative variable. Although this model cannot discriminate which factor is $t^{\prime}$ 'e $n_{n}$. ior control on Li distribution, it highlights that some modalities of di_erent variables (e.g. _lter ee iers, bivalves, benthic, and gonads) are grouped and have higher Li concentrations than others (dem en 11 iver, _sh, and predator of small_sh, in particular). A log-normal linear model accoun ${ }^{+}, \mathrm{I}_{\mathrm{r}}$ all modalities shows that the parameters characterized in this study account for 70\% $\mathrm{f}$ th, observed variability in Li concentrations, and that each is necessary to explain the observed Li distribuı. nn. Abbreviations: FF, _lter feeder; GS, grazer/scavenger; PI, predator of invertebrates; PISM, preda 'r of invertebrates and small_sh; PSM, predator of small _sh; BB, Bay of Biscay; NC, New Caledonia ' ' Y er

Figure 2: Li concentrations ( $\mu \mathrm{g} / \mathrm{g}$ dw $/ \mathrm{l}_{1}$. d 1 _erent marine organisms grouped by biogeographic area and indicating mean annual sea surface to nperature (SST): NC, New Caledonia, SST $=21^{\circ} \mathrm{C}$ (red); BB, Bay of Biscay, SST $=16^{\circ} \mathrm{C}$ (orange); $1^{\circ}$ rrg., Kerguelen Islands, SST $=1{ }^{\circ} \mathrm{C}$ (blue). Abbreviations: Biv., bivalves; Crust., crustaceans; Cep ${ }_{\text {. }}$ cephalopods. Numbers at the right of each plot indicate the number of analyses (n) for each location. " $\mathrm{e}$ note that $\mathrm{n}=5$ for NC and BB crustaceans and NC Pectinidae, $\mathrm{n}=8$ for NC cephalopods, and $n>26$ for other groups. Asterisks indicate p-values from the Mann-WhitneyWilcoxon test (see Suppı $\eta \epsilon_{1}$ ary Material for details) and highlight the signi_cance of the observed di_erences between pairs of sroups: ns (not signi_cant) for $p>0.05$, * for $p<0.05$, ** for $p<0.01$, *** for $p<0.001, * * * *$ for $p<0.0001$ (highly signi_cant di_erence). Outliers are plotted as grey circles.

Figure 3: Box plots showing Li concentrations ( $\mu \mathrm{g} / \mathrm{g} \mathrm{dw}$ ) of (A) all organs/tissues and (B) muscles vs. trophic group. The numbers at the top of each plot indicate the number of analyses for each trophic group (n). Trophic -Outliers are plotted as gray circles. The high variability of Li concentrations observed at the PI level is mainly G. piabilis and G. nicholsi, which are mostly planktivores.

Figure 4: The median and range of Li concentrations $(\mu \mathrm{g} / \mathrm{g} \mathrm{dw}$ - all tissue considered) among di_erent taxonomic groups. The numbers at the top of the plot indicate the number of analyses $(\mathrm{n})$ per taxonomic group. The dashed blue line indicates the seawater Li concentration $(0.18 \mu \mathrm{g} / \mathrm{mL})$. Subdivisions are made by the habitat: benthic species (brown) live on the sea_oor, demersal species (or benthopelagic, orange) move in the water column just above the sea_oor, and pelagic species (yellow) live in the water column. Abbreviations: Biv., bivalves; Crust., crustaceans; Ceph., cephalopods. Asterisks and 'ns' indicate statistical signi_cance as in Figure 2. Outliers are plotted as gray circles.

Figure 5: Li concentrations ( $\mu \mathrm{g} / \mathrm{g} \mathrm{dw})$ measured in the whole body ('whole') and di_erent tissues of the analyzed marine organisms. The dashed blue line indicates the seawater Li concentration $(0.18 \mu \mathrm{g} / \mathrm{mL})$. 
Fish show the greatest variability in Li concentrations, both within each organ type and among di_erent organs. Abbreviations: Biv., bivalves; Crust., crustaceans; Ceph., cephalopods.

Figure 6: Average Li concentrations $(\mu \mathrm{g} / \mathrm{g} \mathrm{dw})$ in the organs of selected sh and bivalve species from the Bay of Biscay. Colors indicate organ types, small gray dots indicate individual analyses, and vertical lines indicate the range of observed values. Abbreviations: PI, predator of invertebrates; PISM, predator of small_sh and invertebrates; FF,_lter-feeders. In most studied species, gills display higher Li concentrations than other organs, whereas muscles and liver show lower Li concentrations.

Figure 7: Average Li concentrations ( $\mu \mathrm{g} / \mathrm{g} \mathrm{dw}$ ) in _sh brain vs. (a) trophic groups and (b) trophic levels. Fish trophic levels are from Froese and Pauly (2020). Small grey circles are individual measurements. Vertical lines re_ect the range of values per trophic group or level. Numbers at the top indicate the number of analyses (n) per trophic group or level. Asterisks and 'ns' indicate statistical signi_cance as in Figure 2. 


\section{Declaration of competing interests}

$\bigotimes$ The authors declare that they have no known competing financial interests or personal relationships that could have appeared to influence the work reported in this paper.

$\square$ The authors declare the following financial interests/personal relationships which may be considered as potential competing interests: 


\section{Credit Author Statement}

NV, PB: Conceptualization, Supervision, Project administration. PB, YC, TLL: Resources. LW, CC: Methodology, Validation, Investigation; FT, LW: Formal analysis, Writing - Original Draft; FT: Vizualization; FT, LW, NV, CC, TLL, MM, YC, PB: Writing - review \& editing 
Graphical abstract

\section{Highlights}

$\mathrm{Li}$ is bio-reduced along the marine trophic webs

Organs involved in osmoregulation processes display the highest Li concentrations The studied parameters are trophic group, habitat, location, and taxonomical group All investigated ecological parameters are necessary to explain Li variability 


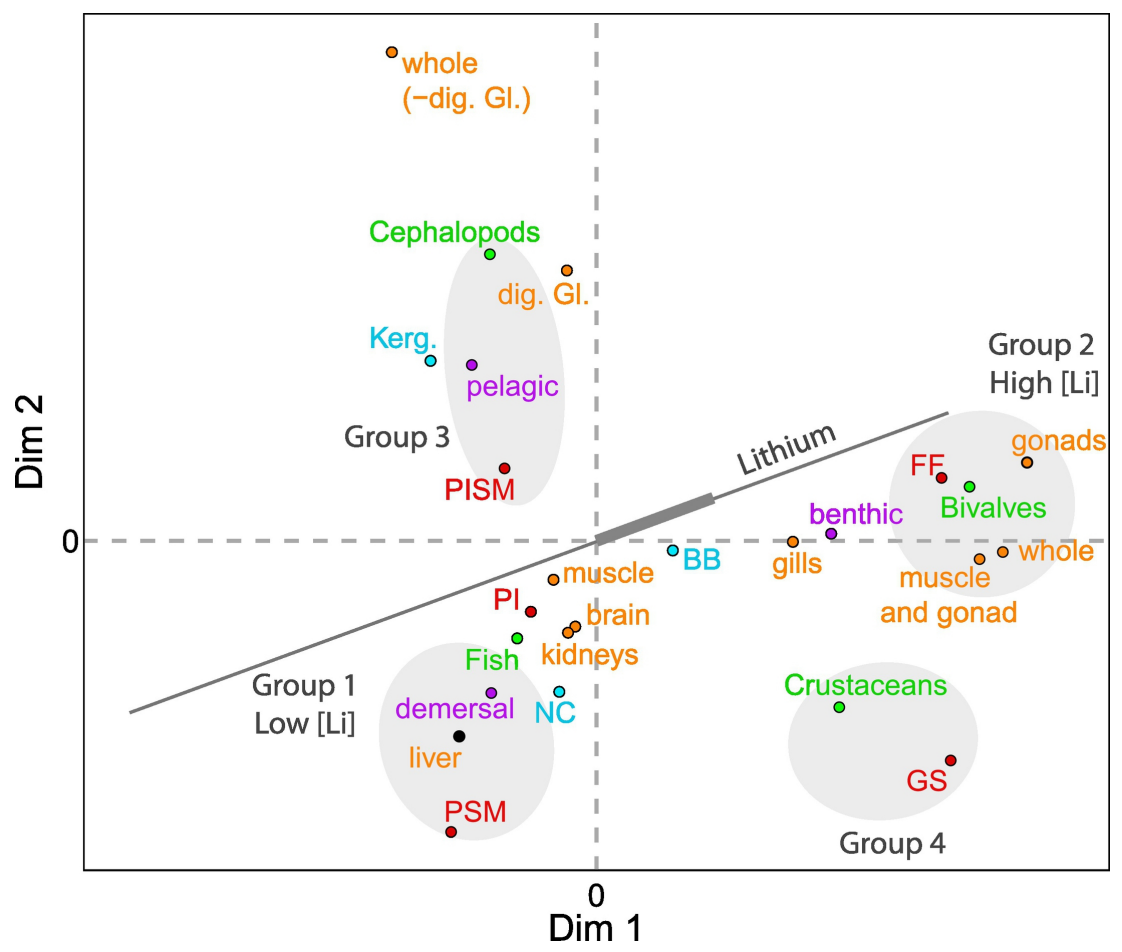

Figure 1 

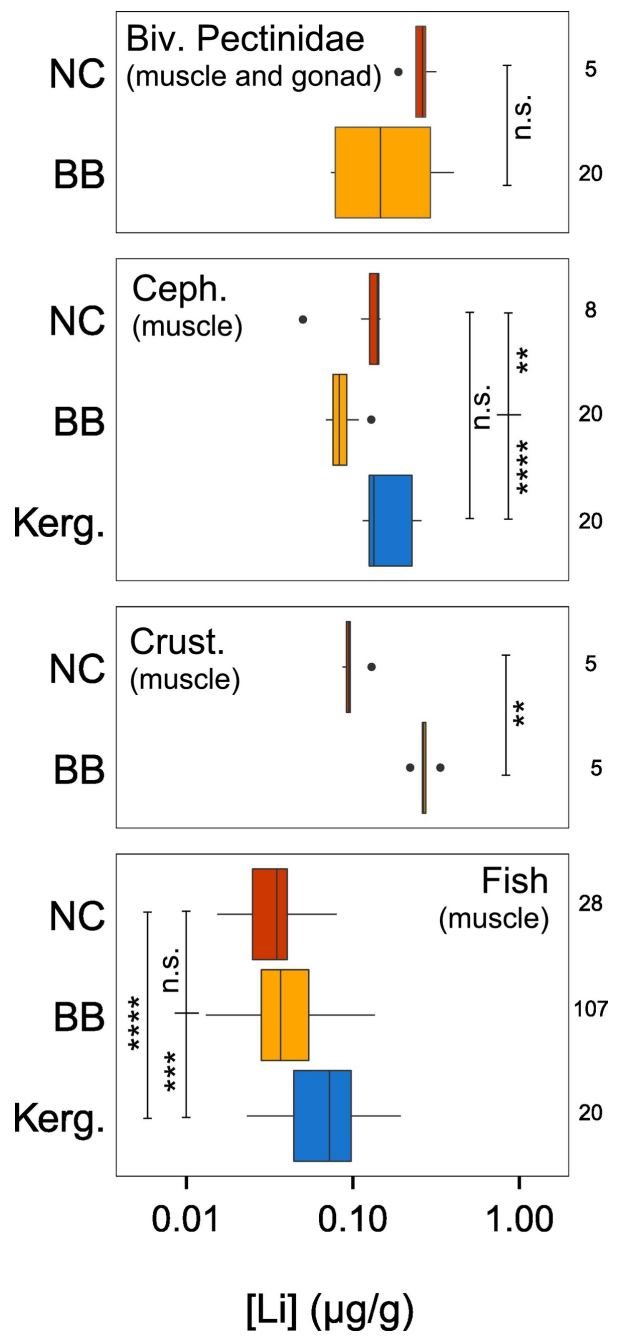

Figure 2 

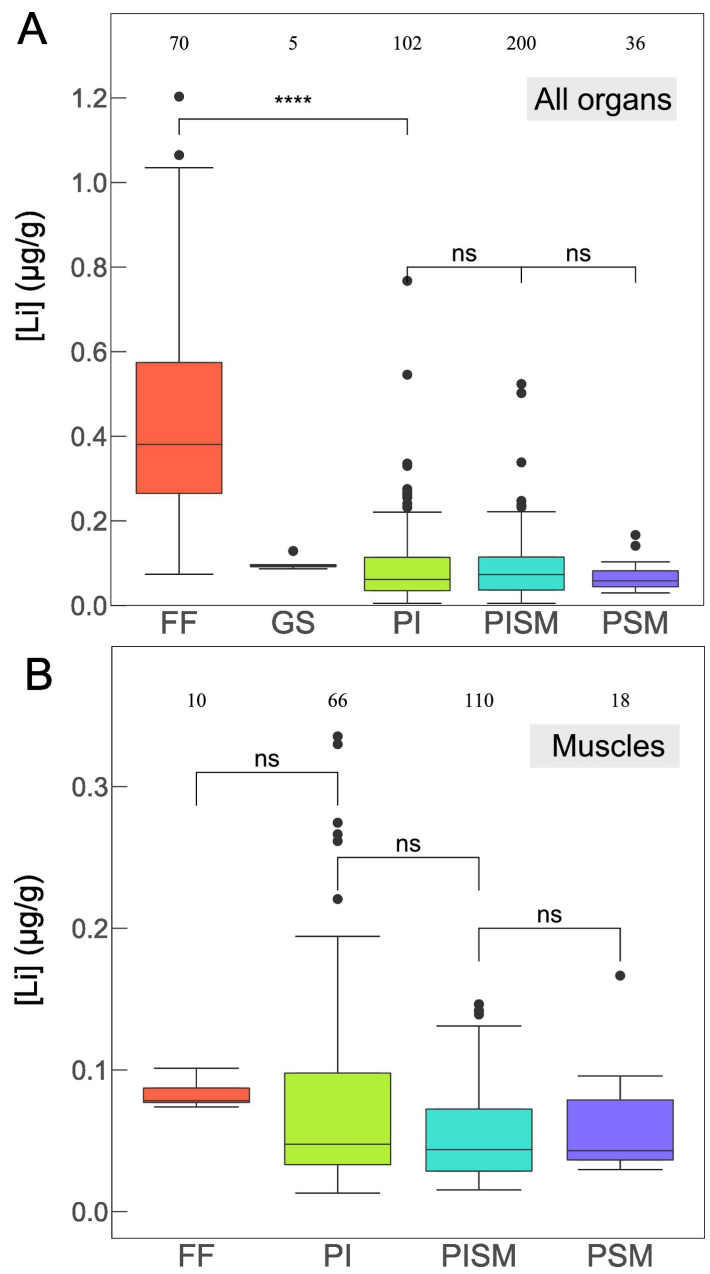

Figure 3 


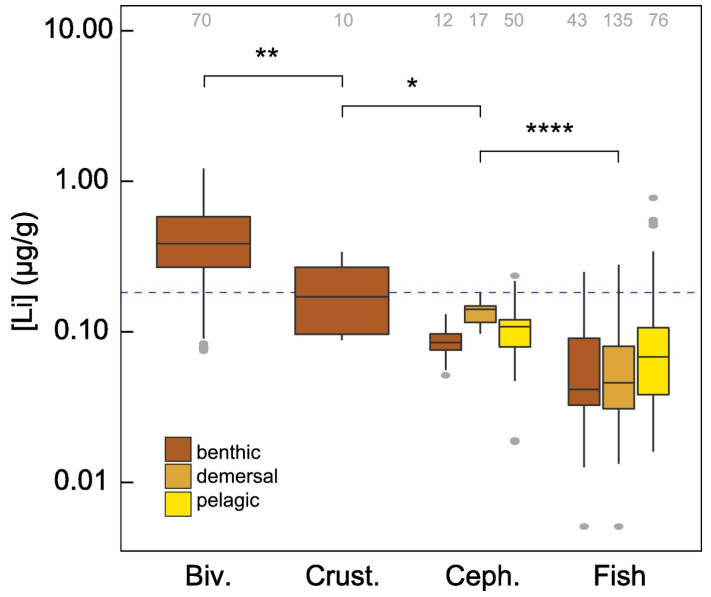

Figure 4 

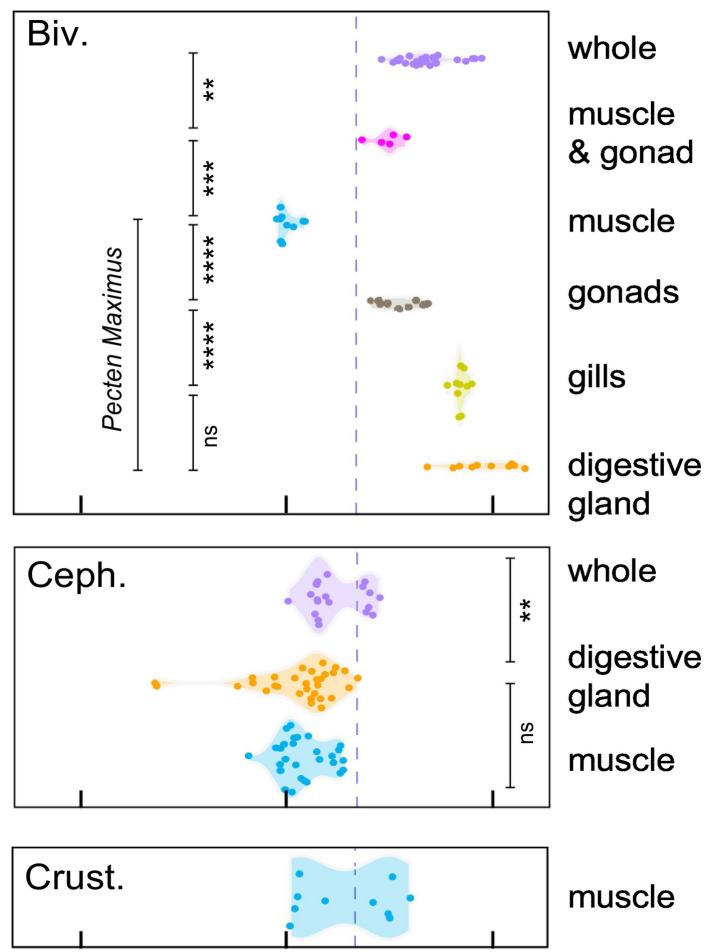

muscle

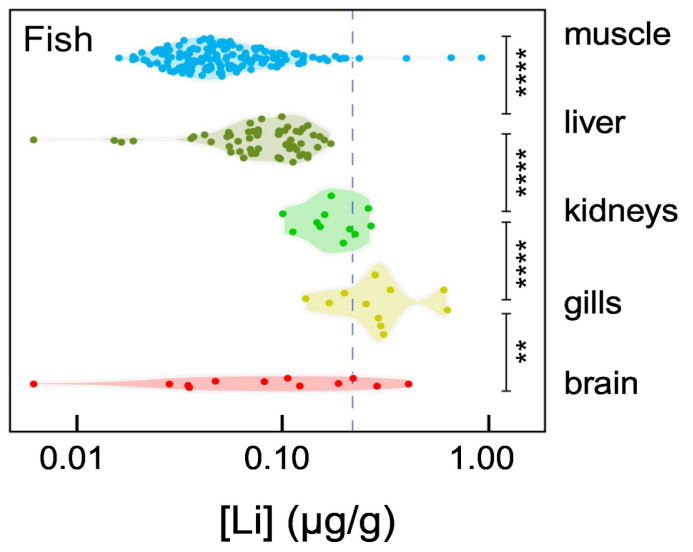

Figure 5 
Fish

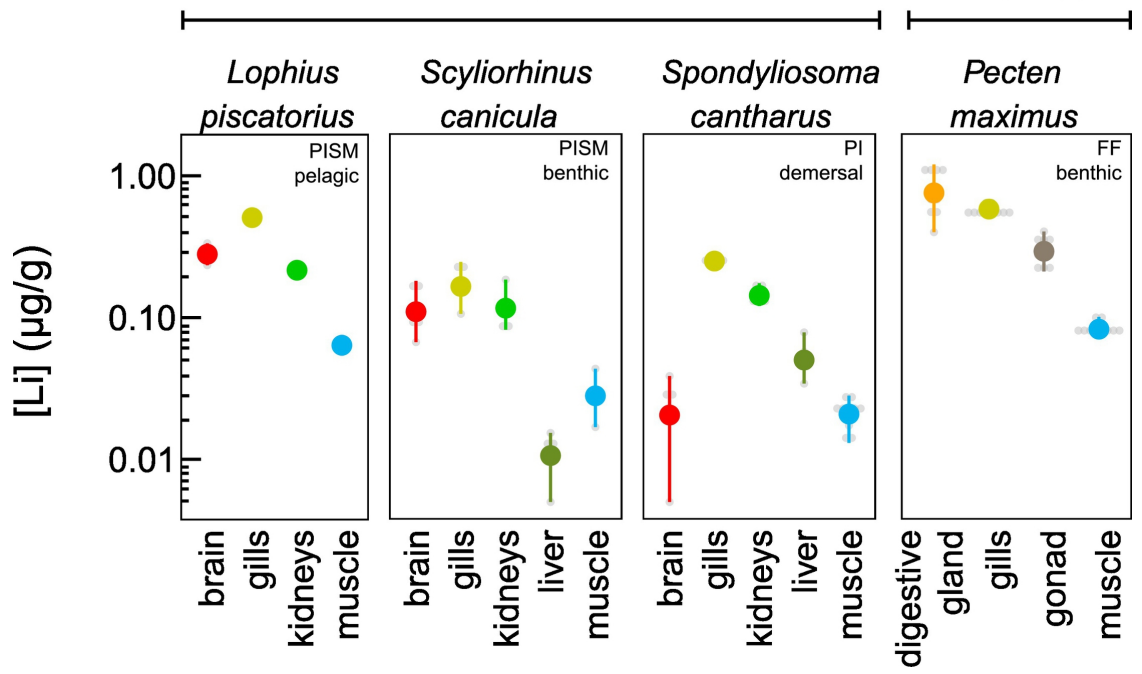

Figure 6 

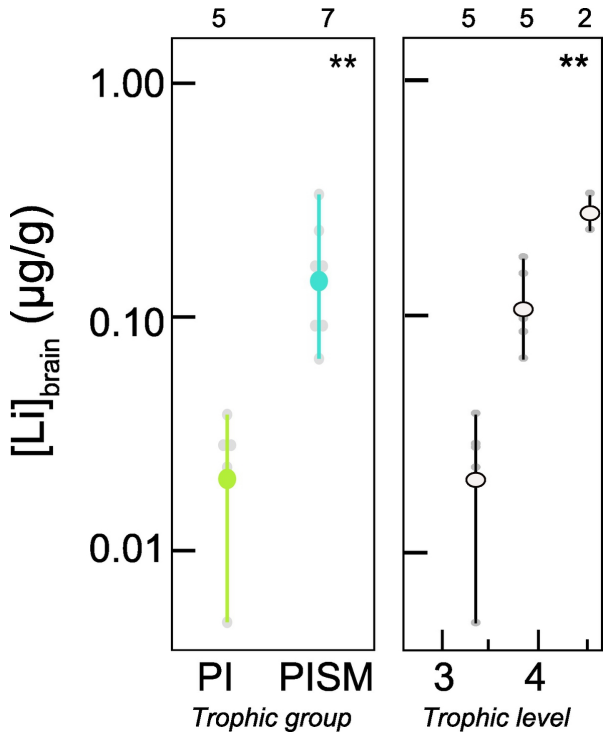

Figure 7 